\title{
SUCCESSOR REPRESENTATION - A THEORETICAL APPROACH IN THE LIGHT OF THE NEW CIVIL CODE \\ C.I. Murzea
}

\section{Cristinel Ioan Murzea}

Law Faculty, Law Departament

Transilvania University, Braşov, Romania

E-mail: cristinel.murzea@unitbv.ro

\begin{abstract}
According to the current legal provisions, successor representation is that legal institution which allows a legal heir of a more distant degree in relation to the defunct, named as a representative, to gather the successor rights of his ascendant, called a represented, whether he renounced his inheritance, he is undignified or he proceeded the time of succession. Successor representation is a distinctive institution from that of representation both in regard to its legal nature and in regard to the effects it produces, a fact which is clearly pointed out in the new Civil Code.
\end{abstract}

Key-words: representation, successor representation, legal fiction, descendents, privileged collaterals

\section{INTRODUCTION}

Amongst the forms in which representation is expressed, a particular one, by notes and judicial legal characters, is successor representation.

In this context, article 965 of the new Civil Code states as follows: „By successor representation, a legal heir of a more distant degree, named a representative, by the effect of law, receives the rights of his ascendant, called a represented, in order to inherit the amount which would have been awarded to his ascendant, had he not been undignified when the inheritance procedures began"

Thus, we notice that, by this article, the lawmaker introduces the representation of the undignified person as a novelty.

In such circumstances, the annulment of the title of heir of the undignified person ${ }^{1}$ does not result in the legal impossibility of him being represented by his descendents. As a consequence, the representatives of the undignified person become heirs by representation and can be awarded parts of the inheritance not only for themselves, as stated in the 1865 code.

Specialty doctrine created several definitions for successor representation, but all of it point out the same legal consequences. Thus, the literature which we believe to be „classical”, by authors such as M. Planiol and G. Ripert define successor representation as ,a legal institution according to which certain heirs, descendents of the same branch as opposed to descendents from another branch, exercise the rights which should have been exercised by their predeceased ascendant, had he survived "de cuius."

On this note, professor Fr. Deak shows that successor representation represents a benefit of the law according to which a legal heir (or more heirs) of a more distant degree called representatives - become heirs by taking over the rights of the ascendant - called a

\footnotetext{
${ }^{1}$ Acording to the Romanian Civil Code, notary guide, The Official Bulletin, Bucharest, 2011, p. 335.

${ }^{2}$ M. Planiol, G. Ripert, Troite pratique de droit civil francaise, Librairie generale de droit et de jurisprudence, vol VI, Paris, 1932, p. 78-80
} 
represented - who is deceased at the time of inheritance in order to gather the part of the inheritance which should have been awarded to the ascendant, had be been alive. ${ }^{3}$

As a consequence, the representative will gather the goods instead of the represented ${ }^{4}$ or the part of the inheritance which should have been awarded to the author of the representative, had he been able to inherit. ${ }^{5}$

These definitions present the essential traits of this institution, as well as the mechanism, the conditions and the effects it produces. ${ }^{6}$

Based on these traits, the lawmaker of the new Civil Code created "succesio in locum" in order to accomplish a complete balance between the different branches. ${ }^{7}$

Recent specialty doctrine showed that by the effect of successor representation, the inheritance is awarded to the most distant descendents "in locum parentis praedefuncti" based on their own right - in jure proprio - an not as a consequence of the rights of the predeceased. ${ }^{8}$

The reasoning behind this legal institution was that there should be an obvious balance between branches; also, there shouldn't be a state of judicial synchronization between brothers and sisters on one hand and descendents on the other hand.

Thus, recent specialty doctrine in France shows that ,if the lawmaker regulated representation, the purpose of this institution was to neutralize hazard and all this was achieved in order to promote the equality of branches". 9

\section{IS THE SUCCESSOR REPRESENTATION “A FICTION OF LAW"?}

Article 664 of the 1865 Civil Code, a rather similar regulation to that of article 738 of the French Civil Code, stated that representation was a fiction of law with the effect of placing the representatives in the place, degree and rights of the represented, a solution which would be subject of criticism from specialty doctrine.

We can easily see that the phrasing according to which representation is ,a fiction of law" is used in an express manner. Thus, the normal question of knowing what this fiction of law was, arose; as a consequence, was the legal mechanism which made representation possible a fiction or not?

"Ad abruptum" we could state an opinion as follows: any representation entails a fiction according to which the representative, by concluding legal acts for the represented, substitutes him, thus resulting in the idea that the representative himself concluded that act.

In this simplified vision, we can assume the existence of fiction by replacing the represented, thus allowing for the representative to valorize the interests of the representative as if he would act ${ }^{10}$

This hypothesis would lead to a simplified and speculative scheme. Thus, doctrine stated a reasoned opinion according to which, in case of conventional representation, there are two distinctive realities. First, there is an agreement between the two legal wills expressed by the conclusion of a representation convention. Second, there is the effective operation of valorizing the interests of the represented by the representative. On the other hand, we can

\footnotetext{
${ }^{3}$ Fr. Deak, Succession law treaty, Universul Juridic Publishing House, Bucharest, 2002, p.78

${ }^{4}$ M. D. Bob, Issues of regulating successor representation in the new Civil Code in R.R.D.P. no 1/2011, p.37

${ }^{5}$ M. C. De Roton-Catala, Droits des parents en l'absence de conjoit succesible, p. 459 cap. 231 in the paper Droit patrimonial de la famille, Dallas, 2011, coordinated by Michel Grimaldi.

${ }^{6}$ C. Murzea, E. Poenaru, Representation in private law, C. H. Beck Publishing House, Bucharest, 2007, p. 80

${ }^{7}$ Ioan Popa, Inheritances and liberalities, Universul Juridic Publishing House, Bucharest, 2013, p. 102

${ }^{8}$ M. Grimaldi, Droite civile. Succesions, Litec, Paris, 2011, p. 136

${ }^{9}$ M. Grimaldi, Droite civile. Succesions, Litec, Paris, 2011, p. 136

${ }^{10}$ C. Murzea, E. Poenaru, op. cit., p. 81
} 


\section{C.I. Murzea}

easily see that the representative manifests his own will in order to fulfill the empowerment provided to him as, regardless of how limited his empowering is, he still has some degree of freedom in making decisions. ${ }^{11}$ The situation is similar in case representation is made by legal or judicial manner.

As opposed to the above mentioned aspects of representation, if fiction would be the simple replacing, we could be discussing ,imperfect fiction” as we can't discuss fiction in the most pure sense of the word because, in this case, there is a convention which involves an agreement between two wills, a situation which is likely to formally invalidate the existence of a legal fiction.

The opinion phrased by professor I. Deleanu is much more trenchant, stating that ,the idea of fiction in the matter or representation must be definitely removed."12

Thus, we are faced with the dilemma of whether, in the matter of representation, the idea of fiction is unacceptable, as would be explained by the „expresis verbis” phrasing of article 664 of the Cuza code, which shows that successor representation is a fiction of law; however, this phrasing is the only mention of this kind. This originates from the lawmaker of Napoleon's Code intention of taking over certain institutions from Roman law, thus influencing the Civil Code of 1865, according to which the existence of a patrimony without a living owner was inconceivable, thus resulting in the introduction of fiction according to which the predeceased heir was considered to be alive, which would allow him to inherit, thus allowing his representative to inherit in his place.

In this context, according to a legal fiction, the represented, although deceased, was considered to be alive, thus being able to inherit; this would result in his representatives becoming heirs in his place. The above mentioned opinion is inexact, as successor partition does not mean the predeceased inherits his part and then transfers it to his heirs; it means that the representative is entitled to inherit by "apae legis". As a result, the representatives do not benefit from fiction of representation, but a fiction by replacing within the same degree. ${ }^{13}$

In a quite clear statement, professor I. Deleanu shows that the inheritance rights of the representative, even if they should have been awarded to the predeceased, ,are not transferred thought the patrimony of the represented", an issues which was also pointed out by classical doctrine represented by M. Planiol and G. Ripert, who showed that ,the representative does not exercise his right as an heir of the represented, but as a personal right, thus the idea according to which everything occurs as if the representative would be alive is not entirely correct." 14

For these reasons, some authors believe that successor representation is an exception from the rules of partition of inheritance ,ab intestat", thus invalidating the idea that all relatives of the same degree are equal.

Thus, professor I. Deleanu mentions that - „the law derogates from the rule of proximity of relatives and the rule of equality of relative of the same degree" 15 .

By analyzing this matter in detail, by using the means of judicial logic and the internal resources which are the basis of these exceptions, we can't ignore the fact that the lawmaker regulates the assumption that the represented is still alive when the procedures for de cuius succession begin. Thus, the lawmaker ignores the obvious reality and creates a „legal fiction”.

In this context, the lawmaker creates, by fiction, legal consequences resulting from a hypothesis which represents it own creation. We agree with the majority opinion phrased by doctrine according to which successor representation is ,a legal fiction according to which the

\footnotetext{
${ }^{11}$ According to P. Vasilescu, The relativity of the civil legal act, Rosetti Publishing House, Bucharest, 2003 , p. 203-204

${ }^{12}$ I. Deleanu, Judicial Fictions, All Beck Publishing House, Bucharest, 2005, p. 443 ,

${ }^{13}$ Ibidem, p. 263

${ }^{14}$ M. Paniol, G. Ripert, op. cit., p. 80-81

${ }^{15}$ I.Deleanu, op.cit., p. 263
} 
mechanism by which the representatives become heirs instead of the predeceased is established" 16 .

Article 751 of the French Civil Code clearly mentions that „representation is a legal fiction which results in calling in succession the representatives to gather the rights of the represented, a situation which clearly abandons the vision phrased by the Roman system of law, according to which the representative becomes heir by effect of his own right ,in locum parentis praedefuncti" thus inheriting a right which belonged to the predeceased ${ }^{17}$.

As a conclusion, we believe that successor representation is an exception from the principle of proximity of relatives between heirs form the same category, as well as from the principle of equality between relatives of the same category and same degree called to inherit. Thus, successor representation is a fiction of law which results in placing the representatives in the place, degree and rights of the represented.

The utility of representation is that, by the effects is produces, it removes some unjust consequences of the principle of proximity of relatives and the principle of equality between relatives of the same degree ${ }^{18}$.

In regard to the area of enforcement, successor representation can apply to descendents of the children of the defunct and descendents from brothers and sisters.

The institution of successor representation is an exception from the principles of the legal partition of the inheritance, thus it derogates from these rules; as these exceptions are to be strictly interpreted, the provisions which regulate these issues have the same legal regime.

As a consequence, no other person can benefit from representing the parents of the defunct or his own parents (uncles or aunts of the defunct). Similarly, the surviving spouse can't inherit by representation from a brother or a parent or any other relatives of the predeceased spouse; also, he can't be represented ${ }^{19}$.

Article 741 of the French Civil Code clearly states that representation is not allowed in regard to decedents.

We notice that the Romanian lawmaker makes no mention of this situation, although the strict interpretation of article 966 first and second alignment would lead to the same conclusion. Article 976 second alignment expressly mentions that ,in order to represent for the inheritance of the defunct, the representative must meet all the general conditions required in order to inherit".

Given the situation that successor representation is an exceptional benefit which the law grants to some heirs, we can't expand it to other heirs, as we lack a formal text of law.

\section{CONCLUSIONS}

This article deals with the issue of representation succession, an institution whose role is to achieve an evident balance between strains.

The successor representation institution is distinct from that of representation in private law, both from the perspective of the judicial nature as well as the legal effects it produces. The theme contains the novelty introduced in Romanian civil law in matters of succession representation by the provisions of the new Civil Code, being also a tool used in the process of interpretation of succesoral law from the doctrinal perspective.

\footnotetext{
${ }^{16}$ I.Popa, op.cit., p.102

${ }^{17}$ Ibidem

${ }^{18}$ Ioana Nicolae, Civil law. Succession. Legal inheritance, Hamangiu Publishing House, 2014, p.97

${ }^{19}$ C.Murzea, E.Poenaru, op.cit., p.85
} 


\section{BIBLIOGRAPHY}

- M. Planiol, G. Ripert, Troite pratique de droit civil francaise, Librairie generale de droit et de jurisprudence, vol VI, Paris, 1932,

- Fr. Deak, Tratat de drept succesoral, Universul Juridic Publishing House, Bucharest, 2002,

- M. D. Bob, Consideraţii asupra reglementării reprezentării succesorale, în Noul Cod Civil in R.R.D.P. nr. 1/2011,

- M. C. De Roton-Catala, Droits des parents en l'absence de conjoit succesible, p. 459 cap. 231 in Droit patrimonial de la famille, Dallas, 2011, coordinated by Michel Grimaldi.

- C. Murzea, E. Poenaru, Reprezentarea în dreptul privat, Edit. C. H. Beck Publishing House, Bucharest, 2007,

- I.Popa, Moşteniri şi liberalităţi, Universul Juridic Publishing House, Bucharest, 2013

- M. Grimaldi, Droite civile. Succesions, Litec, Paris, 2011,

- P. Vasilescu, Relativitatea actului juridic civil, Rosetti Publishing House, Bucharest, 2003,

- Ioana Nicolae, Drept civil. Succesiuni. Moştenirea legală, Hamangiu Publishing House, Bucharest, 2014. 